\title{
Profil kenakalan remaja dan implikasinya terhadap program bimbingan pribadi-sosial
}

\author{
Dieta Dwi Wahyuni*, Meilla Dwi Nurmala \\ Bimbingan dan Konseling FKIP Universitas Sultan Ageng Tirtayasa \\ *Corresponding Author. e-mail: dietadwi3@gmail.com
}

\begin{abstract}
Abstrak
Penelitian ini dilatarbelakangi oleh adanya permasalahan kenakalan remaja yang terjadi pada siswa. Penelitian bertujuan untuk mengetahui gambaran umum kenakalan remaja khususnya pada siswa kelas XI di SMAN 5 Kota Serang, kemudian menyusun program bimbingan pribadi sosial sebagai implikasi dari penelitian untuk mencegah kenakalan remaja. Metode penelitian yang digunakan adalah penelitian deskriptif dengan pendekatan kuantitatif. Teknik pengambilan sampel menggunakan simple random sampling pada 171 siswa. Sedangkan teknik analisis data menggunakan statistik deskriptif. Penelitian mengenai kenakalan remaja dilakukan dengan melihat dua indikator kenakalan remaja yaitu Index Offenses dan Status Offenses sebanyak 36 item dan reliabitas 0,304. Berdasarkan analisis data, hasil penelitian menunjukkan tingkat kenakalan remaja di SMAN 5 Kota Serang berada pada kategori rendah dengan persentase sebesar 87\%. Penyumbang terbesar dari angka ini adalah aspek Status Offenses dengan indikator mengontrol emosi, berbohong, membolos, memalak teman sebaya, merokok, dan perilaku seks pranikah yaitu sebesar $19 \%$ yang termasuk dalam kategori sedang. Setelah mengetahui gambaran umum kenakalan remaja, maka rancangan program dibuat berdasarkan hasil penelitian yang didapat.
\end{abstract}

Kata kunci: kenakalan remaja, program bimbingan

\begin{abstract}
This research is based on the existence of juvenile delinquency problems that occur in students. This study aims to determine the general description of juvenile delinquency, especially in class XI students at SMAN 5 Serang City, then compile a social personal guidance program as an implication of research to prevent juvenile delinquency. The research method used is descriptive research with a quantitative approach. The sampling technique used simple random sampling to 171 students. While the data analysis technique used descriptive statistics. Research on juvenile delinquency was conducted by looking at two indicators of juvenile delinquency, namely 36 items of Offenses Index and Status Offenses and a reliability of 0.304. Based on the data analysis, the results showed that the juvenile delinquency level in SMAN 5 Serang City was in the low category with a percentage of $87 \%$. The biggest contributor to this figure is the aspect of status offenses with indicators of controlling emotions, lying, truancy, bullying peers, smoking, and premarital sex behavior, which is $19 \%$ which is included in the moderate category. After knowing the general description of juvenile delinquency, the program design was made based on the research results obtained.
\end{abstract}

Keywords: juvenile delinquency, guidance program

This is an open-access article under the CC-BY-SA license.

doi https://doi.org/10.21831/foundasia 


\section{PENDAHULUAN}

Remaja adalah masa peralihan dari kanak-kanak menuju dewasa. Seorang remaja sudah tidak lagi dapat dikatakan sebagai kanak-kanak, namun ia masih belum cukup matang untuk dapat dikatakan dewasa. Remaja memiliki rasa ingin tahu yang tinggi (high curiosity), hal tersebut menjadi penyebab bahwa banyak remaja ingin mencoba segala sesuatu yang belum pernah dia coba sebelumnya (Hartinah, 2008).

Para remaja yang mempunyai gengsi yang tinggi akan langsung meniru gaya teman-teman sebayanya, serta ingin diakui dalam kelompoknya tersebut dan dikatakan mengikuti budaya yang sedang banyak dilakukan oleh teman-temannya, karena hal itulah terkadang banyak remaja pada akhirnya tidak fokus sekolah, lebih menyibukkan diri dengan kenakalannya yang akhirnya hal tersebut menyebabkan turunnya prestasi remaja di sekolah.

Menurut Havighurst (Gunarsa, 2001) salah satu tugas perkembangan masa remaja yaitu menerima kenyataan terjadinya perubahan fisik, belajar memiliki peranan sosial dengan teman sebaya, mencapai kebebasan dari ketergantungan terhadap orangtua, mengembangkan kecakapan intelektual, mencari jaminan bahwa mampu berdiri sendiri, mempersiapkan diri untuk menentukan suatu pekerjaan, memamahi dan mampu bertingkah laku yang dapat di pertanggung jawabkan, memperoleh informasi tentang pernikahan, dan mendapatkan penilaian bahwa dirinya mampu bersikap tepat sesuai dengan pandangan ilmiah. Hal yang sama terjadi, dibuktikan dengan penelitian yang dilakukan oleh Tri, H. Pada tahun 2014 yaitu bahwa bimbingan sosial sangat penting karena didorong oleh bimbingan sosial, maka siswa akan terus berperilaku dan bertingkahlaku sesuai dengan bimbingan yang diperoleh di sekolah sehingga akan berpengaruh terhadap penurunan tingkat kenakalan remaja. Sumbang efektif variabel bimbingan sosial dan bimbingan pribadi secara besamasama terhadap kenakalan remaja adalah kecil sebesar 22,63\%.

Aspek yang dikemukakan oleh Santrock yang juga dijadikan pedoman oleh peneliti dalam membuat instrumen mengenai kenakalan remaja dijelaskan antara lain: (1) Index Offenses. Tindakan kriminal yang dilakukan oleh remaja maupun orang dewasa. Tindakan kriminal tersebut diantaranya adalah pencurian, melakukan kekerasan pada orang lain, dan menggunakan obat-obatan terlarang. (2) Status Offenses. Tindakan yang tidak terlalu serius dan biasanya dilakukan oleh anak muda di bawah usia tertentu. Tindakan ini disebut sebagai pelanggaran remaja seperti mengontrol emosi negatif, berbohong, membolos, memalak teman, merokok, dan orientasi seks pranikah.

Menurut Asmani (2012) kenakalan remaja yang sering dilakukan sekolah yaitu rambut panjang bagi siswa putra, rambut disemir, merokok, berkelahi, mencuri, pacaran, tidak masuk sekolah, sering bolos, tidak disiplin, ramai di dalam kelas, mengotori kelas dan halaman sekolah. Maka program bimbingan dalam penelitian ini dirancang atas permasalahan kenakalan remaja sebagai permasalahan pribadi yang juga memiliki dampak pada permasalahan sosial. Oleh karena itu rangkaian layanan meliputi bidang pribadi dan sosial. Penanganan kenakalan remaja bukan hanya saat permasalahan terjadi, namun dibutuhkan juga upaya preventif sebelum permasalahan kenakalan remaja datang. Jika guru BK atau Konselor sekolah tidak siaga dalam menghadapi permasalahan seperti kenakalan remaja, maka semakin banyak para siswa yang mengalami hal yang sama berdampak pula pada lingkungan sosialnya. Perlu adanya program bimbingan pribadi sosial yang dapat membantu individu dalam memecahkan masalah-masalah pribadi maupun sosial sebagai bagian dari implikasi terhadap permasalahan yang terjadi.

\section{METODE PENELITIAN}

Metode penelitian yang digunakan oleh peneliti adalah metode kuantitatif dengan Teknik deskriptif. Penelitian dilakukan di SMAN 5 Kota Serang yang terletak di Jl. Ayip Usman No. 26, Kaligandu Kota Serang, Banten. Waktu penelitian dimulai pada bulan Januari 2019 untuk perijinan melakukan penelitian. Alasan peneliti melakukan penelitian di SMAN 5 Kota Serang karena melihat selama peneliti melakukan PPLK-BK di sekolah ini terdapat beberapa permasalahan anak yang 
melakukan kenakalan remaja. Penelitian ini mengambil subyek penelitian yaitu siswa kelas XI di SMAN 5 Kota Serang Tahun Ajaran 2019/2020 yang berjumlah 315 orang dengan pengambilan sampel menggunakan teknik simple random sampling sebanyak 171 siswa. Teknik pengumpulan data yang digunakan peneliti yaitu menggunakan instrument penelitian berupa angket yang berisi pernyataan yang harus diisi oleh responden mengenai kenakalan remaja. Pada angket kenakalan remaja terdapat 36 item pernyataan dengan menggunakan 4 alternatif jawaban SS (Sangat Setuju), S (Setuju), TS (Tidak Setuju), dan STS (Sangat Tidak Setuju). Alternatif jawaban tersebut memiliki rentang skor 1-4 dengan 4 sebagai skor tertinggi dan 1 sebagai skor terendah. Sebelum dilakukan penelitian, peneliti terlebih dahulu melakukan uji validitas dan uji reliabilitas terhadap kenakalan remaja, sehingga didapatkan hasil bahwa skala kenakalan remaja telah valid dan reliabel.

\section{HASIL DAN PEMBAHASAN}

Berdasarkan deskripsi hasil data kenakalan remaja, didapatkan hasil penelitian yang menunjukkan sebanyak 3 siswa atau 2\% berada pada kategori tinggi. Sebanyak 21 siswa atau $11 \%$ berada pada kategori sedang, sedangkan sebanyak 150 siswa atau $87 \%$ berada pada kategori rendah, artinya 150 siswa yang berada dalam kategori rendah memiliki tingkat kenakalan remaja lebih rendah dibandingkan dengan kategori tinggi.

Hasil penelitian menunjukkan bahwa kenakalan remaja siswa kelas XI di SMAN 5 Kota Serang secara umum berada pada kategori rendah yaitu sebesar $87 \%$. Kategori rendah berarti siswa hanya sedikit yang melakukan kenakalan remaja berupa pelanggaran-pelanggaran di sekolah tersebut, walaupun demikian kenakalan remaja pada siswa yang tergolong rendah sebagai pelanggaran, tetap perlu diupayakan penanggulangannya. Kenakalan remaja di SMAN 5 Kota Serang ini perlu diatasi agar tidak meningkat, kenakalan siswa dapat diupayakan pencegahannya melalui peran orang tua, guru, dan lingkungan sekitar. Peran sekolah sangat dibutuhkan untuk mendidik remaja menjadi pribadi yang lebih baik. Peran sekolah ini meliputi semua guru yang ada di SMAN 5 Kota Serang. Guru adalah orang yang secara langsung berinteraksi dengan siswa dalam proses pembelajaran di kelas. Oleh karena itu guru bertanggung jawab mendidik siswanya menjadi pribadi yang lebih baik.

Berdasarkan hasil tingkat kenakalan remaja yang secara umum berada pada kategori rendah, namun demikian sekecil apapun kenakalan remaja perlu ada upaya pembinaan dan pencegahan sedini mungkin dari pihak sekolah, karena kebiasaan melakukan perbuatan atau tindakan yang kurang baik atau negatif jika dibiarkan akan menjadi suatu karakter atau kebiasaan yang kurang baik bagi perkembangan individu siswa itu sendiri. Seperti dikemukakan oleh Willis (2005) bahwa upaya preventif atau pencegahan lebih besar manfaatnya daripada upaya kuratif (penyembuhan), karena jika kenakalan itu sudah meluas amat sulit menanggulanginya. Banyak bahayanya kepada masyarakat, menghamburkan biaya, tenaga, dan waktu sedangkan hasilnya tidak seberapa. Oleh karena itu upaya preventif (pencegahan) itu sangat penting dan kegiatan ini dilakukan secara sistematis, berencana, dan terarah untuk menjaga agar kenakalan itu tidak timbul.

Sesuai dengan peran dan fungsinya, keberadaan guru BK sangat diharapkan untuk mampu melakukan pembinaan dan mengatasi kenakalan remaja yang dilakukan oleh para remaja usia khususnya di sekolah berperan aktif dalam mengatasi kenakalan yang terjadi dikalangan siswa, hal ini untuk mencegah kerusakan moral yang lebih parah yang dapat merusak masa depan siswa yang bersangkutan, sehingga siswa yang bermasalah dapat berkembang ke arah yang positif dan lebih menguntungkan dirinya. Adapun upaya guru BK mencegah kenakalan remaja pada siswa di SMAN 5 Kota Serang agar tidak meningkat atau tetap pada kategori rendah dengan cara pembinaan dan pencegahan.

\section{Index Offenses}

Hasil dari penelitian secara umum siswa dengan persentase sebesar 94\% atau sebanyak 161 orang berada pada kategori rendah. Sedangkan sebesar 6\% atau 10 orang berada pada kategori sedang. Artinya siswa ada sedikit kecenderungan kenakalan remaja yang melakukan pencurian, kekerasan pada oranglain, dan menggunakan obat-obatan terlarang. 
Pencurian menurut Kamus Besar Bahasa Indonsesia, arti dari kata "curi” adalah mengambil milik orang lain tanpa izin atau dengan tidak sah, biasanya dengan sembunyi-sembunyi. Melakukan kekerasan pada orang lain adalah suatu perbuatan yang disengaja dengan suatu bentuk aksi atau perbuatan kelalaian yang dilakukan tanpa suatu pembelaan atau dasar kebenaran dan diberikan sanksi oleh Negara sebagai suatu tindak pidana berat atau tindakan pelanggaran hukum yang ringan (Santoso, 2003).

Menggunakan obat-obatan terlarang atau penyalahgunaan narkoba merupakan suatu ancaman dan permasalahan komplek yang dapat menghancurkan generasi muda. Penyalahgunaan obat-obatan terlarang bisa mengakibatkan kecanduan dan mengakibatkan gangguan secara klinis atau fungsi sosial. Oleh karena itu, pentingnya penyuluhan untuk menambah pengetahuan seputar obat-obatan terlarang atau narkoba (Ricardo, 2010).

\section{Status Offenses}

Hasil dari penelitian secara umum siswa dengan persentase sebesar $79 \%$ atau sebanyak 136 siswa berada pada kategori rendah. Sedangkan sebesar 19\% atau sebanyak 32 siswa berada pada kategori sedang, dan sebesar $2 \%$ atau sebanyak 3 siswa dalam kategori tinggi. Mengontrol emosi yaitu kemampuan individu untuk dapat mengendalikan dirinya. Mampu mengontrol emosi berarti remaja tersebut mampu menunda sesuatu. Hal tersebut senada dengan pernyataan Goleman (Hariwijaya, 2005:7) bahwa pengelolaan emosi merupakan salah satu bagian dari kecerdasan emosi yang penting untuk dimiliki individu dalam meraih keberhasilan.

Berbohong menurut Elfindri (2012) perkataan apa adanya, misalnya dalam jujur berarti lurus hati, tidak berbohong, tidak curang (dalam permainan atau ujian) dan senantiasa mengikuti peraturan yang berlaku. Membolos biasa dilakukan oleh siswa yang malas untuk datang ke sekolah dan malas untuk mengikuti jam pelajaran yang tidak disukai. Hal ini disebabkan oleh faktor lingkungan sekolah, masyarakat, dan kurangnya pengawasan dari guru. Faktor lingkungan sekolah disebabkan karena dari ajakan teman-temannya, sedangkan faktor masyarakat karena lingkungan atau tempat tinggal yang kurang baik.

Memalak teman sebaya, menurut penelitian Bagus (2014) yaitu dorongan dan penyebab siswa SMA melakukan tindak pemalakan adalah ingin dianggap jagoan, biasanya mereka bertindak memalak ini hanya untuk diakui jagoan saja agar teman-temannya ini segan kepadanya. Merokok merupakan suatu kebiasaan negatif yang mulai melanda seluruh kalangan baik dari dewasa bahkan kalangan pelajar, dengan adanya permasalahan tersebut tentunya dibutuhkan kepekaan dari seluruh warga sekolah, serta memberikan keteladanan bagi siswanya, meskipun sudah ada peraturan tentang larangan merokok di lingkungan sekolah namun jika tidak diberikan teladan, siswa juga tidak akan melaksanakan peraturan yang ada secara maksimal. Perilaku seks pra nikah, pengetahuan seksual pranikah penting diberikan kepada remaja, baik melalui pendidikan formal maupun informal agar remaja terhindar dari perilaku seksual pranikah (Chyntia, 2007).

\section{SIMPULAN}

Berdasarkan hasil penelitian diperoleh beberapa kesimpulan antara lain: (1) Secara umum siswa SMAN 5 Kota Serang tingkat kenakalan remaja pada kategori rendah, yaitu sebesar $87 \%$. Penyumbang kenakalan remaja kelas XI di SMAN 5 Kota Serang bersumber dari aspek Status Offenses dengan indikator mengontrol emosi, berbohong, membolos, memalak teman sebaya, merokok, dan perilaku seks pranikah pada kategori sedang yaitu sebesar 19\%. (2) Program bimbingan pribadi sosial disusun sesuai dengan Prosedur Operasional Penyelenggaraan Bimbingan dan Konseling di Sekolah Menengah Atas (POP BK SMA). Adapun rancangan program bimbingan pribadi sosial dianataranya: rasional, dasar hukum, visi dan misi, deskripsi kebutuhan, tujuan, rencana operasional (action plan), pengembangan tema/topik, strategi layanan, evaluasi dan tindak lanjut, sarana dan prasarana serta anggaran biaya.

Berdasarkan hasil penelitian yang dilakukan pada siswa kelas XI di SMAN 5 Kota Serang, berikut beberapa saran yang diharapkan dapat memberikan masukan yang bermanfaat bagi: (1) Guru Bimbingan dan Konseling dapat memanfaatkan program bimbingan untuk mempertahankan kondisi kenakalan remaja yang rendah dan mencegah kenakalan remaja pada siswa. Selain itu, guru Bimbingan dan konseling dapat memberikan berupa penanganan pada siswa yang berkategori sedang 
pada kenakalan remaja dengan memberikan bantuan layanan berupa konseling. (2) Pihak sekolah, dapat dijadikan landasan dalam pengambilan keputusan dalam pengelolaan peserta didik mengenai fenomena kenakalan remaja di lembaga pendidikan. (3) Jurusan Bimbingan dan Konseling, dapat memberikan informasi bagi pengelolaan pendidikan dan pengajar agar lebih memahami faktor-faktor yang berkenan dengan kenakalan remaja. (4) Peneliti selanjutnya dapat memperkaya kajian penelitian ini dengan meneliti variabel lain yang diperkirakan berhubungan dengan kenakalan remaja. Selain itu dapat menguji evektifitas program bimbingan yang telah dirancang..

\section{DAFTAR PUSTAKA}

Asmani, J.M. (2012). Kiat Mengatasi Kenakalan Remaja. Yogyakarta: Diva Press.

Bagus, H. K.(2014). Perilaku Memalak Siswa SMA dan Manajemen Layanan Khusus Penanggulangannya. Malang. Skripsi tidak diterbitkan

Cynthia, T. (2011). Konformitas kelompok dan perilaku seks bebas pada remaja. Jurnal Psikologi, $1(1)$.

Elfindri. (2012). Pendidikan Karakter: Kerangka, Metode dan Aplikasi untuk Pendidikan dan Profesional. Jakarta: Baduose Media

Gunarsa, S.D. (2001). Psikologi Praktis: Anak, Remaja, dan Keluarga. Jakarta: BPK Gunung Mulia

Hariwijaya. (2005). Tes Kecerdasan Emosional. Yogyakarta: Pustaka Pelajar.

Hartinah, S. (2008). Perkembangan Peserta Didik. Bandung: PT. Refika Aditama

Santoso, T. (2003). Teori-teori Kekerasan. Jakarta: Ghalia Indonesia

Willis, S. (2005). Remaja dan Masalahnya: Mengupas berbagai bentuk kenakalan remaja, seperti narkoba, free sex, dan pencegahannya. Bandung: Alfabeta. 